Altered Inheritance 



\title{
FRANÇOISE BAYLIS
}

\section{Altered \\ Inheritance}

\section{CRISPR and}

\author{
the Ethics
}

of Human

Genome

\section{Editing}

II Harvard University Press Cambridge, Massachusetts London, England 2019 
Copyright (C 2019 by the President and Fellows of Harvard College All rights reserved

Printed in the United States of America

First printing

Cover design: Tim Jones

Cover image: Getty Images

9780674241961 (EPUB)

9780674241978 (MOBI)

9780674241954 (PDF)

Many of the designations used by manufacturers and sellers to distinguish their products are claimed as trademarks. Where those designations appear in this book and Harvard University Press was aware of a trademark claim, then the designations have been printed in initial capital letters.

The Library of Congress has cataloged the printed edition as follows:

Names: Baylis, Françoise, 1961- author.

Title: Altered inheritance : CRISPR and the ethics of human genome editing/ Françoise Baylis.

Description: Cambridge, Massachusetts : Harvard University Press, 2019. I Includes bibliographical references and index.

Identifiers: LCCN 2019009524 I ISBN 9780674976719 (alk. paper)

Subjects: LCSH: Gene editing-Moral and ethical aspects. I CRISPR (Genetics) I Genetic engineering-Risk assessment. I Medical ethics.

Classification: LCC QH438.7 .B38 2019 | DDC 576.5-dc23 LC record available at https://lccn.loc.gov/2019009524 
TO MY PARENTs, Richard and Gloria Baylis, who taught me about courage and integrity 
